\title{
COMPETENCE-CENTRED EDUCATION OF OFFICERS THOUGHTS ABOUT A RECENT RESEARCH OF COMPETENCIES IN MILITARY AVIATION MAINTENANCE
}

\author{
Péter SZEGEDI \\ Hungarian Defence Forces, Education \& Training Directorate, Budapest, Hungary \\ szegedidr.peter@gmail.com \\ József TÓTH \\ National University of Public Service, Budapest, Hungary \\ toth.jozsef@uni-nke.hu \\ Károly TURCSÁNYI \\ National University of Public Service, Budapest, Hungary \\ turcsanyi.karoly@uni-nke.hu
}

\begin{abstract}
Highly trained professionals are an addition to the 21st century military organizations that means an utmost challenge for our education systems. The amount, variety and quality of all sorts of profes-sionalisms required by today's warfare technologies are the crucial requirements to match for today's and tomorrow's military recruiters and educators. This article is a try to disseminate some ideas and thoughts concerning the development and improvement of the present educational portfolio by a more proper understanding of the wants and needs of the military workplace through the example of the research and analysis of aircraft maintenance officers and their professional competencies.
\end{abstract}

KEYWORD: research, aviation, engineering, competency, military, officer, management, knowledge

\section{Introduction}

Military aviation is one of the probably most technically challenging area of military engineering, management and leadership. It comprises of a wide range of distinct professions cooperating with the final purpose of safe execution of airborne operations. Despite the fact that the technological and organizational sides of the activities involved has undergone an evolution without a match in the traditional areas of activity of the Hungarian Defence Force, it is safe to state that the human resources requirements of the new tasks and technologies of today are more than difficult to match.

The human side of military aviation has become probably the most important challenge that our military education system might be able to take up. We would need decades to improve enough on the technological side to be able to add anything 
relatively important and useful to the common European effort to develop and improve military aviation - we might, however, be able to develop our education of the personnel so that they can successfully cooperate with their NATO counterparts in the common concern to keep the skies safe. In order to do so, however, the education system needs to be revised and improved on a regular basis following the permanent changes in the technology, practice and theory of military aviation. Monitoring such changes and provide their results as an input for the system of military education modernization is therefore of utmost importance. Due to the complexity of the area and the changes, a complex knowledge management scheme of creating, collecting, storing and channelling information to the decision making processes of all relevant areas will be required (OECD, 2001; Koronváry, 2008a; Tomka, 2009; Koronváry, 2014a; Koronváry, 2014b; Bencsik, 2015; Békési, Koronváry \& Szegedi, 2015; Koronváry \& Szegedi, 2015a; Szegedi, 2016a; Tóth, 2016c).

In order to do so, relevant competencies have to be properly identified and mapped. Competencies are the means, behaviours, capabilities, motivations and know-how required to reach targeted objectives of individual tasks to be done when filling a certain position. Certain competencies will therefore be presumably universal, others will, in their combination, resemble and qualify the organization or one or more of its parts or layers, others will combine so that they will be particularly resembling a certain well-identified part or layer of a particular organization; and there will be combinations that are special to certain positions or even one single task. Competency patterns therefore may be used to identify behaviour patterns expected in a certain position, in certain units, parts or layers of the organization, or in a specific organization as opposed others. But it also works vice versa: competencies in practice may be defined by the behaviour patterns shown by individuals in the position, unit, part or layer of a specific organization. In order to be able to develop the right competencies, they must be defined, described, and analysed. A 2016 research of the militaty aviation maintenance personnel provides a good example (Koronváry 2008b; Klein \& Klein, 2012; Szegedi, 2014; Koronváry \& Szegedi 2015b; Koronváry \& Szegedi 2016).

In the recent years there have been a number of new approaches appearing in and around the Hungarian Defence Force concerning the identification and development of competencies, and their use in theory and in practice. They usually stress the importance of personal practical experience. Such approaches emphasise how individuals interpret tasks, classify and organize their knowledge, com-petencies, skills etc., and how they identify themselves with certain combinations rather than with others (Koronváry, 2009). In order to identify and analyse competencies necessary in various jobs of military aviation engineering and maintenance, we find such approaches extremely useful. One of the interesting approaches in 2016 was provided by József Tóth's $\mathrm{PhD}$ reseach who, under the supervision of LTC Péter Szegedi, and COL (ret.) Károly Turcsányi set up an integrative scheme suitable for the analysis of competencies required in military aviation maintenance positions.

\section{Monitoring \\ 2. The Necessity of Permanent}

Social and technological changes in the Hungarian defence sector have altered the structure, tasks and concepts of the Hungarian Defence Force in all its parts and layers. Military aviation has not been exempt of these changes. A continuous reassessment of its competencies and the communication of the results towards staff and decision makers alike are in the interest of the organization. Any research in this 
field should have aims and objectives that help to build a knowledge base of synchronous data patterns as well as a diachronic one to be able to establish and identify trends and tendencies for further analysis.

\section{The Choice of Sampling}

In case that a representative set of information of the present status is requested, the analysis of all the competency and knowledge patterns of individuals filling the chosen type of positions will be unavoidable. In case of military aviation engineering, for example, these can be all those air force positions that require an aviation engineering degree. With such a selection the competency model can directly be tailored to the needs of the organization under scrutiny. Desk research and preliminary interviews may gather enough information to set up a first list of names and positions, then each interviewee should be asked to offer further names to grow and improve the sample. Such a rolling research can go on as long as the provided data and information becomes repetitive, that is when the theoretical saturation level is reached (Horváth \& Mitev, 2015).

Interview should cover information on the interviewee's life, military career, motivation, profes-sional interest, experience etc.

In a recent trial research, for example, personal interviews were made on 32 different sites with 45 individuals. In terms of professional experience, most interviewees had at least 5 years of practice in aviation maintenance. As an average, they had 3 years of maintenance experience with Gripens, and none of them had less than 4 years of professional practice. The average time of professional experience with other makes of airplanes added up to 8 years, changing from 3 to 25 years. The research found that this pattern represents the whole of the aviation engineering population, not only those in maintenance. As they shown, other findings of their research may also be generalized in this way.

\section{4. "Soft" Methodology in Use}

In order to verify or falsify the hypotheses, the research must get answers to a number of details that are difficult or impossible to quantify. Part of the research therefore must use "qualitative" rather than "quantitative" methods of investigation (Antal, 1976; Gordon \& Langmaid, 1997; Langer, 2009; Koronváry, Szegedi \& Tóth, 2015; Szegedi, 2016b). The choice of semistructural interviews seems to be advantageous as the interviewee has some freedom to offer in-formation not targeted by the interviewer's questions. After informing the interviewee about the aims and objectives of the research and their role, including the legal issues concerning the methodology (e.g. the use of video recordings), the interviewee has to be asked for their agreement to continue.

The semistructured interviews followed these steps:

\section{Scenario:}

1. Main line: semi-structured (career) interview.

2. Selecting sample: pensioned, inactive, or active military officers with military aviation (or similar) degree and/or experience.

3. Doing the interview: meeting at an agreed date and place, agreement to take part and to recording the interview.

II. Interview outline:

1. Introductions, objectives, topics: introduction of the interviewer, informing the interviewee about legal issues and freedom of opinion, giving background information on the research objectives, structure, time needed etc.

2. Warm-up: free talk on military career and profession. Creating the right atmosphere (15 $\mathrm{min}$.):

- Why did you choose the military aviation engineering career? 
- Whose opinion did you ask for when choosing this profession?

- Who or what motivated you?

- What were the years at the Military Academy or College like?

- Tell me about your professional development and career!

3. Unstructured discussion (50 min.).

4. Thanking and departure (5 min.).

The analysis of the interviews aim at the standardization of the data received, the creation of infor-mation and the gaining of knowledge out of the answers. With the help of the audiovisual materials also the meta-communication of the interviewees can be analysed.

The interdisciplinary content analysis provides the researcher with documentation showing the data, connections, relationships and causalities in their complexity. The data can be kept in a database of defined categories that are to be identified on the basis of the data themselves. Due to the qualitative nature of the competencies, mutual exclusivity is not absolutely necessary to reach. Tóth's (2016a) research managed to identify four major groups of qualities he labelled "What?"-s, "How?"-s, "Competencies" and "Forms of Behaviour", each containing 12 to 19 different qualities. The identified behavioural patterns, as he has shown, may be used as the basis of the second phase, the questionnaire research.

\section{The Questionnaire Research}

The aim of the second phase has been to identify statistical relationships between the data. The use of questionnaires may provide representativeness and the creation of statistically analysable data. It provides the researcher with results that are general or can be generalised. If the research is repeated regularly, these data can be used for the identification and analysis of trends (Antal, 1976; Gordon \& Langmaid, 1997; Héra \& Ligeti 2006; Langer, 2009; Koronváry, Szegedi \& Tóth, 2015; Szegedi \& Tóth 2016).
The secondary aim is to gain such information that did only partially - or not at all - appear in the interviews. The new input can present the researcher with data and information that helps identify the relevance and importance of individual competencies, their role in certain positions, even to map the difference between the competency patterns requested in leadership and nonleading positions. Also they may help to differentiate between competencies needed in operating various technologies or even certain types of aviation methodologies, tools, planes etc. In plain English, they may clear interdependencies between operations strategies and methodologies and competency patterns.

The questionnaires and their analysis according to Tóth therefore looks for answers for the following questions:

- Which of the competencies or qualities does the respondent find important?

- How would they order them according to importance?

- Which competencies or qualities do they find more important to possess by persons in leading positions?

- Which competencies and qualities are those which are more important for those operating Gripens?

- Are there any competencies and qualities that are exclusively linked to the operation of Gripens?

The first part of the questionnaire in the original research therefore concentrates on general data like the details of the education needed for the responder's present position, their highest professional qualification, and the highest-level professional training they have taken part.

In the second part, questions concentrate on the professional careers, the positions they have filled already, as commanders or managers with masters degree or subordinates with masters degree, as commanders or managers as bachelors degree or subordinates with bachelors degree, or as senior leaders. 
Other question was asked about the aviation technologies with which the respondents have worked (Turcsányi, Szegedi \& Tóth, 2016b).

The answers provided information for the grouping of respondents in order to show what groups may possess relevant information on which professional competencies are based.

\section{Findings}

The research identified and contacted 152 people with relevant experience and received 89 answers. The high ratio of respondents proves the interest, motivation and support of the profession to invest extra time and energy in a research project that may help their work in the future (Tóth, 2016a; Tóth, 2016c; Turcsányi, Szegedi \& Tóth 2016a).

The results have shown that $46 \%$ of the respondents received a command post within six years after acquiring a bachelor's degree in military arts or military engineering. Typically the highest level of education in their career line is that of a master's degree that $45.3 \%$ of the respondents have already possessed and also they have been in positions requiring it for at least a year. $22 \%$ of them had more than 5 years experience in positions offering relevant high-level professional experience.

Concerning the factual, theoretical knowledge the respondents identified eight highly important qualities to be essential. Concerning practical skills and know-how, such qualities received an evaluation of at least 3 out of 5 , showing that acquaintance with technological solutions and practice is taken for more important as theoretical knowledge.

As far as skills and capabilities are concerned, technical intelligence, hands-on experience and the ability to work autonomously (self-management) have been among the most highly evaluated qualities. Also the personal needs for selfimprovement and professional development as well as the abil-ity to learn from one's own faults gained high marks.

With relation to the attitudes of concern, the respondents have stressed the importance of trustworthiness, punctuality and precision, and professional credibility. Beside them, there were seven other qualities receiving high (above an average of 4 out of 5) marks. Skills connected to the keeping of the meticulous military protocols, however, have received lower marks showing that the professional culture of the participants emphasises primarily the engineering or technological side of responsibilities rather than the military ones.

Those respondents who are or have been involved in the maintenance of JAS-39 airplanes emphasised the importance of English language skills and communication beside professional discipline, consistency and keeping to the technological specifications. Those colleagues who have been working in "hard time" time of operation schemes put higher emphasis on detailed knowledge of systems and components, physical strength, but also creativity and problem solving skills.

\section{Conclusions}

As we have shown, the research scheme set up and tried by József Tóth under the supervision and guidance of Péter Szegedi and Károly Turcsányi has proved successful in providing us with new information on the professional competencies requested in aviation maintenance positions. The integrated research comprising of a quantitative and a qualitative part has opened new ways to interpret aviation maintenance jobs and offered valuable information for the educational reforms necessary in this field. Also, the research scheme used has proven to be flexible enough to be further developed and adapted to other professional groups within the Hungarian military force as well as outside of it. 
Such results, if they are provided from everywhere in the national defence system, will offer a solid basis for the development of several professional areas within our human resources management including recruiting and selection, education and training, or career planning and development. The introduction of such a research scheme on a regular basis may therefore be a corner stone of the provision of quality professionals for various military positions including military engineering and aviation posts.

\section{REFERENCES}

Antal, L. (1976). A tartalomelemzés alapjai. Budapest: Magvető Kiadó.

Békési, B., Koronváry, P. \& Szegedi, P. (2015). Terrorism and Airport Security Some Technological Possibilities to Reduce Exposure. Deterioration, Dependability, Diagnostics International conference, Brno: University of Defence, 279-288.

Bencsik, A. (2015). A tudásmenedzsment elméletben és gyakorlatban. Budapest: Akadémiai Kiadó.

Gordon, W. \& Langmaid, R. (1997). Kvalitatív piackutatás Gyakorlati kézikönyv. Budapest: HVG Kiadói Rt.

Héra, G. \& Ligeti, Gy. (2006). Módszertan Bevezetés a társadalmi jelenségek kutatásába. Budapest: Osiris Kiadó.

Horváth, D. \& Mitev, A. (2015), Alternatív kvalitativ kutatási kézikönyv, Budapest: Alinea Kiadó.

Klein, B. \& Klein, S. (2012). A szervezet lelke. Budapest: Edge 2000 Kiadó.

Koronváry, P. (2008a). Az amerikai ,military leadership” elmélet rendszertana (PhD értekezés), Budapest: Zrínyi Miklós Nemzetvédelmi Egyetem, Hadtudományi Doktori Iskola.

Koronváry, P. (2008b). Gondolatok a vezetéstudomány feladatáról. Hadmérnök, III, 161-168. Available at: http://hadmernok.hu/ archivum/2008/2/2008 2 koronvary.pdf.

Koronváry, P. (2009). Rendszertan: elektronikus bevezetö jegyzet a ZMNE hallgatói és a helyi önkormányzatok vezetői számára, Budapest: Zrínyi Miklós Nemzetvédelmi Egyetem.

Koronváry, P. (2014a). Kicsoda a vezető?: Gondolatok a vezetői felelősségről. Hadmérnök IX, 290-295, available at: http://hadmernok.hu/143 24 koronvary 2.pdf.

Koronváry, P. (2014b). TQM a közszférában? veszélyek és lehetőségek. Hadmérnök, $I X, 281-289$, available at: http://hadmernok.hu/143_23 koronvary_1.pdf.

Koronváry, P. \& Szegedi, P. (2015a). Thoughts on Understanding Our Organizations. Hadmérnök, X, 227-236, available at: http://www.hadmernok.hu/154_21 koronvaryp_szp.pdf.

Koronváry, P. \& Szegedi, P. (2015b). Tudásalkalmazás és tudásgondozás. Hadmérnök, X, 217-226, available at: http://www.hadmernok.hu /154 20 koronvaryp szp.pdf.

Koronváry, P. \& Szegedi, P. (2016). 3. Repülögép üzembentartó szervezetek humán erőforrásának tudásalapú fejlesztése. Repülömüszaki üzembentartó szervezetek müködésével, fejlesztésével kapcsolatban Tanulmánykötet a BSc, MSc hallgatók számára. Szeged, 49-63, available at: https://ludita.uni-nke.hu/repozitorium/bitstream/handle/11410/10227/Tanulm\%C3\% Alny-Repm\%C5\%B1szaki.pdf?sequence=1\&isAllowed=y.

Koronváry, P., Szegedi, P. \& Tóth, J. (2015). Kutatás és képzés - módszertani felvetések az elvárások és a képzési portfólió összehangolására a repülőmüszaki képzésben, Hadmérnök, X, 237-246, available at: http://www.hadmernok.hu/154_22 koronvaryp szp tj.pdf.

Langer, K. (2009). Kvalitatív kutatási technikák, Gödöllő: Szent István Egyetemi Kiadó. 
OECD. (2001). Tudásmenedzsment a tanuló társadalomban, oktatás és készségek, available at: http://www.oecdbookshop.org/get-it.php?REF=5LMQCR2JCGG1\&TYPE=browse.

Szegedi, P. (2014). „ÖTLET! ... ROHAM!” egy „csináld és tanítsd” folyamat elindításához, a katonai felsővezető képzés lehetséges fejlesztési iránya. Hadmérnök, IX, 400-408, available at: http://hadmernok.hu/142 35 szegedip.pdf.

Szegedi, P. (2016a). A pilóta nélküli repüléshez kapcsolódva... Tanulmány a pilóta nélküli légijármüvek müködésével és üzembentartásával kapcsolatban, available at: http://m.ludita.uni-nke.hu/repozitorium/bitstream/handle/11410/10148/Tanulmany_Szegedi\% 20K\%C3\%A9 sz_20160407.pdf? sequence $=4 \&$ is Allowed $=\mathrm{y}$.

Szegedi, P. (2016b). Egy non-profit szervezet értékeinek közvetitése tömeg kommunikációs csator-nákon keresztül, tanulmány a magyar honvédség hagyományainak, jelképeinek, tradícióinak, értékeinek közvetithetöségéröl, available at: https://ludita.uninke.hu/repozitorium/bitstream/handle/11410/10149/tanulma-ny2 szegedi peter.pdf?sequence= 1\&isallowed=y.

Szegedi, P. \& Tóth, J. (2016). Repülőgép üzembentartó szervezetek humán eröforrásának kompetencia vizsgálata kvalitativ módszerrel, Repülömüszaki üzembentartó szervezetek müködésével, fejlesztésével kapcsolatban Tanulmánykötet a BSc, MSc hallgatók számára, available at: https://ludita.uni-nke.hu/repozitorium/bitstream/handle/11410/10227/ Tanulm\%C3\%A1ny-Repm\%C5\%B1szaki.pdf? sequence=1\&isAllowed=y.

Tomka, J. (2009). A megosztott tudás hatalom. Budapest: Harmat Kiadó.

Tóth, J. (2016a). An integrated research of aircraft maintenance officer competencies, The $18^{\text {th }}$ Internatonal Conference "Scientific Research and Education in the Air Force" AFASES 2016, The International Conference of Scientific Papers, Volume II, 775-781, Braşov, Romania.

Tóth, J. (2016b). A repülö müszaki tiszti kompetenciák kvalitatív vizsgálata. Repüléstudományi Szemelvények, NKE Katonai Repülő Intézet, Szolnok, 177-196, available at: http://www.repulestudomany .hu/kiadvanyok/RepSzem-2016.pdf.

Tóth, J. (2016c). Компетентностный подход модернизации образования инженеров по эксплуатации современных летательных аппаратов, Repüléstudományi Közlemények, XXVIII, 49.-53, available at: http://www.repulestudomany.hu/index_rtk.html.

Turcsányi, K., Szegedi, P. \& Tóth J. (2016a). Определение компетенций офицеров авиационных инженеров Repüléstudományi Közlemények (1997-TÖL) XXVIII, 7-14.

Turcsányi, K., Szegedi, P. \& Tóth, J. (2016b). A katonai repülőmüszaki tiszti kompetenciák felmérése integrált kutatási módszerrel. Repüléstudományi Közlemények, XXVIII, 153-164, available at: http://www.repul estudomany.hu/index rtk.html. 